\title{
Range expansion of the invasive corals Tubastraea coccinea and Tubastraea tagusensis in the Southwest Atlantic
}

Received: 17 September 2010/ Accepted: 3 January 2011/Published online: 30 January 2011

(C) Springer-Verlag 2011
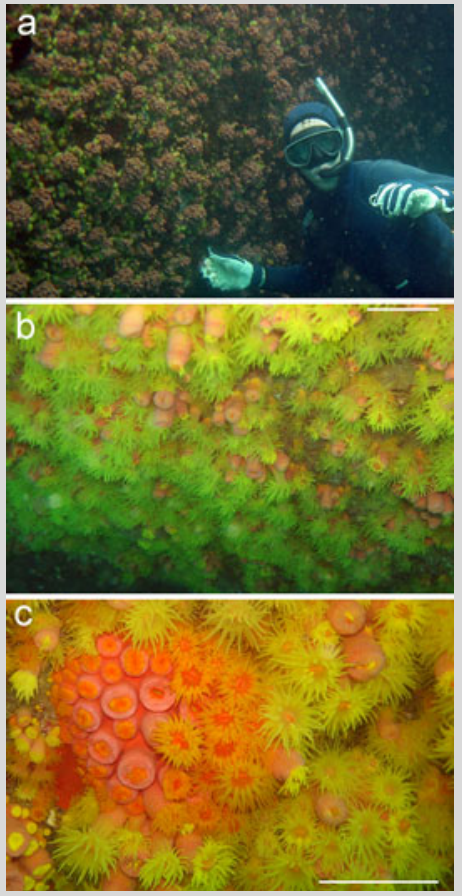

Fig. 1 Southernmost record of Tubastraea on rocky shores in the Atlantic Ocean (Búzios Island, São Paulo State, Brazil): a Tubastraea tagusensis dominating the benthos on a vertical rocky wall at 2 meters depth, b colonies of Tubastraea tagusensis with open polyps on a shaded negative face, c detail of Tubastraea coccinea (left, orange colony) among Tubastraea tagusensis colonies. Scale bars $\mathbf{b}, \mathbf{c}: 5 \mathrm{~cm}$
Corals of the genus Tubastraea (Scleractinia: Dendrophylliidae) invaded the Southwest Atlantic in the 1980s, but remained restricted in distribution to Ilha Grande and Arraial do Cabo, two regions within the state of Rio de Janeiro, Brazil (Ferreira 2003; De Paula and Creed 2004). Here, we report a 130-km southwestward range expansion of Tubastraea coccinea and T. tagusensis to Búzios $\left(23^{\circ} 47.437^{\prime} \mathrm{S} ; 4^{\circ} 08.653^{\prime} \mathrm{W}\right)$ and Vitória Islands $\left(23^{\circ} 44.879^{\prime} \mathrm{S}\right.$; $45^{\circ} 00.918^{\prime} \mathrm{W}$ ), state of São Paulo, Brazil (Fig. 1). The Búzios Island sites were first discovered in July 2008, where the colonies were observed in high abundances at $0.5-15 \mathrm{~m}$ depth. Subsequently, dives in 2009 and 2010 revealed additional sites at the same Island, as well as Vitória Island, representing the southernmost records and the first known range expansion of both Tubastraea species in the southwest Atlantic Ocean. The rocky shore communities at the newly reported sites are dominated by the zoanthid Palythoa caribaeorum, algal turfs and sponges, as well as by the scleractinians Madracis decactis and Mussismilia hispida, the latter being endemic to the SW Atlantic. Since the invasive Tubastraea spp. cover nearly $100 \%$ of the benthos in some locations (Fig. 1), they have likely displaced native benthic species (Creed 2006). Given predictions of temperature increase for this century, these invasive corals may expand their ranges further southward in the SW Atlantic. Long-term monitoring of marginal reef sites as reported herein are needed in order to investigate the development of opportunistic tropical corals.

\section{References}

Creed JC (2006) Two invasive alien azooxanthellate corals, Tubastraea coccinea and Tubastraea tagusensis, dominate the native zooxanthellate Mussismilia hispida in Brazil. Coral Reefs 25:350

De Paula AF, Creed JC (2004) Two species of the coral Tubastraea (Cnidaria, Scleractinia) in Brazil: A case of accidental introduction. Bull Mar Sci 74:175-183 Ferreira CEL (2003) Non-indigenous corals at marginal sites. Coral Reefs 22:498

\section{C. Mantelatto $(\bowtie) \cdot$ J. C. Creed}

Dep. de Ecologia, Universidade do Estado do Rio de Janeiro, Rua São Francisco Xavier 524, Rio de Janeiro, RJ 20550-900, Brazil

e-mail: mcmantel@hotmail.com

\section{G. G. Mourão}

Instituto Terra \& Mar, Caixa Postal 83, Ilhabela, SP 11630-000, Brazil

\section{A. E. Migotto}

Centro de Biologia Marinha, Universidade de São Paulo, São Sebastião, SP 11600-000, Brazil

A. Lindner

Dep. de Ecologia e Zoologia, Universidade Federal de Santa Catarina, Florianópolis, SC 88040-970, Brazil

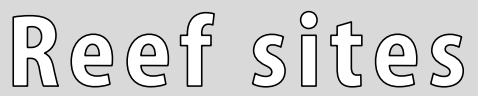

Coral Reefs (2011) 30:397 DOI $10.1007 / \mathrm{s} 00338-011-0720-\mathrm{z}$ 